\title{
Factors Affecting Surgical Waiting Time in Cancer Patients at Referral Hospitals of West Java Province
}

\author{
Yuli Susanti, ${ }^{1}$ Siska Nia Irasanti, ${ }^{1}$ Ieva Baniasih Akbar, ${ }^{2}$ Wawang S. Sukarya ${ }^{3}$ \\ ${ }^{1}$ Department of Public Health, Faculty of Medicine, Universitas Islam Bandung, Bandung, Indonesia, \\ ${ }^{2}$ Department of Physiology, Faculty of Medicine, Universitas Islam Bandung, Bandung, Indonesia, \\ ${ }_{3}^{3}$ Department of Obstetrics and Gynecology, Faculty of Medicine, Universitas Islam Bandung, Bandung, Indonesia
}

\begin{abstract}
A challenge for hospitals in facing the high number of patient visits is to provide quality services. One of the vital services in dealing with patients, especially those who will have cancer surgery considering the high rate of mortality cancer, is an improvement in waiting time (WT). Waiting time for elective surgery is one indicator of service quality with a standard of $\leq 2$ days. This research aimed to determine the average WT for surgery, influencing factors, and optimal queuing models. The method used was quantitative and qualitative methods applied to 207 samples with consecutive sampling at West Java Provincial Al-Ihsan Regional General Hospital Bandung from October to December 2016. The analysis used partial least squares (PLS). The results of the study showed that the average WT for surgery was 32 days. Factors that influence WT were inpatient rooms, number of medical personnel, condition of patients, and health insurance. The optimal queue model to reduce surgical waiting time are adding inpatient beds, oncologist doctor, and creating an online system for registration and confirmation of inpatient rooms and operating.
\end{abstract}

Key words: Queue model, service quality, surgery waiting time

\section{Faktor yang Memengaruhi Waktu Tunggu Operasi Pasien Kanker di Rumah Sakit Rujukan Jawa Barat}

\begin{abstract}
Abstrak
Tantangan bagi rumah sakit dalam menghadapi jumlah kunjungan pasien yang tinggi adalah mampu memberikan pelayanan berkualitas. Salah satu pelayanan signifikan bagi pasien kanker yang akan menjalani operasi adalah perbaikan waktu tunggu karena mortalitas pasien kanker yang tinggi. Waktu tunggu operasi elektif merupakan salah satu indikator mutu pelayanan dengan standar $\leq 2$ hari. Penelitian bertujuan mengetahui waktu tunggu operasi rerata, faktor yang memengaruhi, dan model antrean yang optimal. Metode yang digunakan adalah kuantitatif dan kualitatif yang diterapkan pada 207 sampel secara consecutive sampling di RSUD Al-Ihsan Provinsi Jawa Barat Bandung dari Oktober hingga Desember 2016. Analisis menggunakan partial least squares (PLS). Hasil penelitian menunjukkan bahwa waktu tunggu operasi rerata adalah 32 hari. Faktor yang berpengaruh terhadap waktu tunggu operasi adalah ruang rawat inap, jumlah tenaga medis, kondisi pasien, dan jaminan kesehatan. Model antrean yang optimal untuk menurunkan waktu tunggu operasi adalah penambahan tempat tidur rawat inap, penambahan dokter spesialis bedah onkologi, serta pembuatan sistem daring untuk pendaftaran dan konfirmasi kesiapan ruang rawat inap dan ruang operasi.
\end{abstract}

Kata kunci: Model antrean, mutu pelayanan, waktu tunggu operasi

Received: 28 May 2020; Revised: 13 July 2020; Accepted: 28 July 2020; Published: 31 August 2020

Correspondence: Yuli Susanti, MD. Department of Public Health, Faculty of Medicine, Universitas Islam Bandung. Jln. Tamansari No. 22, Bandung 40116, West Java, Indonesia. E-mail: yulisusantiarmandha@gmail.com 


\section{Introduction}

A hospital as a place to conduct health care is required to provide excellent services. The queue in several hospital units is one of the phenomena that appear in the era of universal health coverage. ${ }^{1}$ This matter contributes to progressivity disease such as malignancy. Malignancy is the most familiar as a characterization of cancer. ${ }^{2}$

Cancer is one of the main causes of death worldwide. In 2012, there were around 8.2 million deaths caused by cancer, and the number of patients with cancer increases every year. ${ }^{2}$ Based on the GLOBOCAN (International Agency for Research on Cancer) data in 2018, it was estimated that there are 18.1 million new cases of cancer. This prediction is assumed to increase in the future. ${ }^{3}$ Breast cancer is the most commonly diagnosed cancer in females and the leading cause of cancer death worldwide. ${ }^{4}$ According to the Basic Health Research (Riskesdas) 2013, the prevalence of cancer in all ages in Indonesia was $0.14 \%$ or 347,792 people. West Java placed the third rank in the province with the highest estimated number of patients with cancer in Indonesia after Central Java and East Java as many as 45,473 people. $^{5}$

Based on the Decree of the Minister of Health Republic of Indonesia (Kepmenkes) Number 129/Menkes/SK/II/2008 concerning Hospital Minimum Service Standards, the waiting time for surgery (operation) is a period since the doctors decide to do a planned operation (elective) until the operation is carried out with the standard waiting time less than or equal to two days ( $\leq 2$ days). ${ }^{6}$

The waiting time for surgery in Dharmais Cancer Hospital Jakarta is 5.39 days, ${ }^{7}$ while it can take 3-6 months in Dr. Hasan Sadikin General Hospital (RSHS) Bandung. ${ }^{8}$ It showed that the minimum service standards stipulated by the Ministry of Health have not been fulfilled yet. The waiting time for surgery among breast cancer patient in Norway began decreasing from 2011 and 2014 after using the cancer patient pathway (CPP) that can be described as a set maximum days' patients experienced from the hospital receives the referral to the first specialist visit, to a clinical decision and to start of treatment. ${ }^{9}$

Many children wait too long for surgery in Canada. Specific attention is required, particularly in dentistry, ophthalmology, plastic surgery, and cancer care. Improved access may be realized with the use of national wait-time targets. ${ }^{10}$ This research aimed to provide an overview of average waiting time in cancer surgery patients, to analyze the influencing factors, and to acquire optimal queueing models.

\section{Methods}

This research used a mixed method of qualitative and quantitative with a cross-sectional design. The quantitative method was implemented by doing observation and survey techniques to get information about waiting time and factors that affect surgical waiting time. The survey instrument was developed with 19 questions about medical staff, management, and hospital facilities, health insurance, and patient conditions. The dimensions included in the questionnaire listed in Table 1.

The response was obtained from 207 cancer patients consecutively sampling at West Java Provincial Al-Ihsan Regional General Hospital from October to December 2016. The samples accomplish inclusion criteria: 1. National Health Insurance patients with cancer diagnose, 2. operative action with a referral, 3. the patient was in the hospital at the time of the study, and 4. patients who were willing to be a respondent.

The three-point Likert response format (ranging from good $=3$, fair $=2$, and poor $=1$ ). The data analysis used partial least squares (PLS) to analyze factors influencing the operation waiting time.

The qualitative method used interviews and focus group discussions to understand information about the surgery queue. The qualitative method used purposive sampling in specific target groups that were capable of providing the needed information was from 18 people. They were medical doctors, surgeons, oncologists, anesthesiologists, nurses, hospital managers (director/vice director, head of ward services, head of outpatient services, and hospital staff).

The discussion starts with the average waiting time in the hospital and tries to find the causes of long waiting time in cancer patients. The results are categorized into four categories: medical staff, management, and hospital facilities, health insurance, and patient conditions. This study had approved by the Health Research Ethics Committee of the Faculty of Medicine, Universitas Padjadjaran, Bandung, Indonesia, 


\section{Table 1 Questionnaire Dimensions}

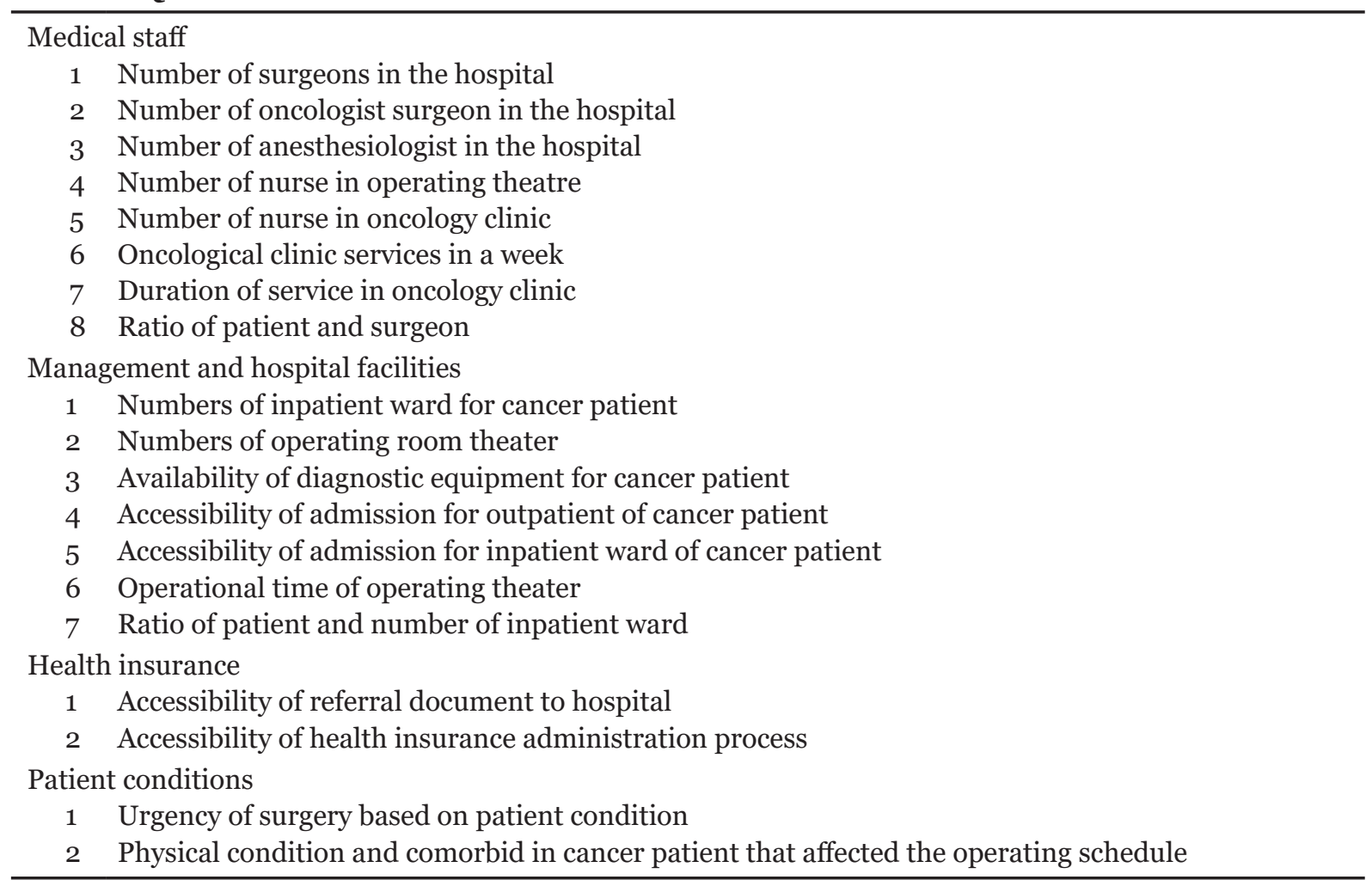

through the issuance of the ethical clearance number: LB.04.01/A05/EC/335/XI/2016.

\section{Results}

The waiting time for elective surgery at referral hospital was calculated based on three parameters; (1) the date of the first visit to the hospital as a patient, (2) the approval date of surgery from the oncologist, (3) and the date of surgery. Based on the three parameters, patient waiting times obtained: the waiting time for the operation (calculated from the approval date of operation to the time of operation, and the total patient waiting time (calculated from the first date of registering as a patient until the time of surgery). The waiting time for surgery and the total patient waiting time in the West Java Provincial Al-Ihsan Regional General Hospital were 32-days and 63-days, respectively.

Based on the national standards set by Kepmenkes Number 129/Menkes/SK/II/2008, the surgery waiting time indicator does not meet minimum service standards. ${ }^{6}$ The confirmatory factor analysis (CFA) is used to evaluate the causality relationship between indicators and latent variables shown in the convergent validity measure. Convergent validity was seen from the assessment of the validity and reliability of measurements. ${ }^{11}$

Based on Table 2, it can be seen that all the factors in each construct of medical staff (TM), management and hospital facilities (MRS), health insurance (HL), and patient condition (PAS) have a loading factor, $\lambda \geq 0.5$. It shows that all factors are valid, while $C R$ values were $>0.7$ and $V E>0.5$. It indicates that all the variables were reliable. ${ }^{11}$

The evaluation of convergent validity is the evaluation of the average variance extracted (AVE) value. AVE results on each construct were above 0.5 , so it concluded that the construct had a good convergent validity. ${ }^{12}$

Analysis of structural models among variables formed from the measurement models. In this research, there are four exogenous variables and one endogenous variable. Exogenous variables are medical staff (TM), management and hospital facilities (MRS), health insurance (HEALTH), and patients (PASIEN). Furthermore, the endogenous variable included in this research 
Table 2 CFA Validity and Reliability

\begin{tabular}{lcccccc}
\hline Latent Variable & Manifest Variable & $\boldsymbol{\lambda}$ & $\boldsymbol{\lambda} \mathbf{2}$ & $\mathbf{e}$ & $\mathbf{C R}$ & $\mathbf{V E}$ \\
\hline TM & TM1 & 0.637 & 0.637 & 0.363 & 0.94 & 0.7 \\
& TM2 & 0.696 & 0.696 & 0.304 & & \\
TM3 & 0.770 & 0.770 & 0.230 & & \\
& TM4 & 0.699 & 0.699 & 0.301 & & \\
TM5 & 0.796 & 0.796 & 0.204 & & \\
TM6 & 0.781 & 0.781 & 0.219 & & \\
& TM7 & 0.779 & 0.779 & 0.221 & & \\
MRS & TM8 & 0.668 & 0.668 & 0.332 & & \\
& MRS1 & 0.789 & 0.789 & 0.211 & 0.96 & \\
& MRS2 & 0.829 & 0.829 & 0.171 & & \\
& MRS3 & 0.870 & 0.87 & 0.130 & & \\
& MRS4 & 0.770 & 0.77 & 0.230 & & \\
& MRS5 & 0.774 & 0.774 & 0.226 & & \\
HL & MRS6 & 0.757 & 0.757 & 0.243 & & \\
& MRS7 & 0.778 & 0.778 & 0.222 & & \\
& HL1 & 0.902 & 0.902 & 0.098 & 0.94 & \\
& HL2 & 0.885 & 0.885 & 0.115 & & \\
& PAS1 & 0.858 & 0.858 & 0.142 & 0.91 & 0.9 \\
& PAS2 & 0.856 & 0.856 & 0.144 & &
\end{tabular}

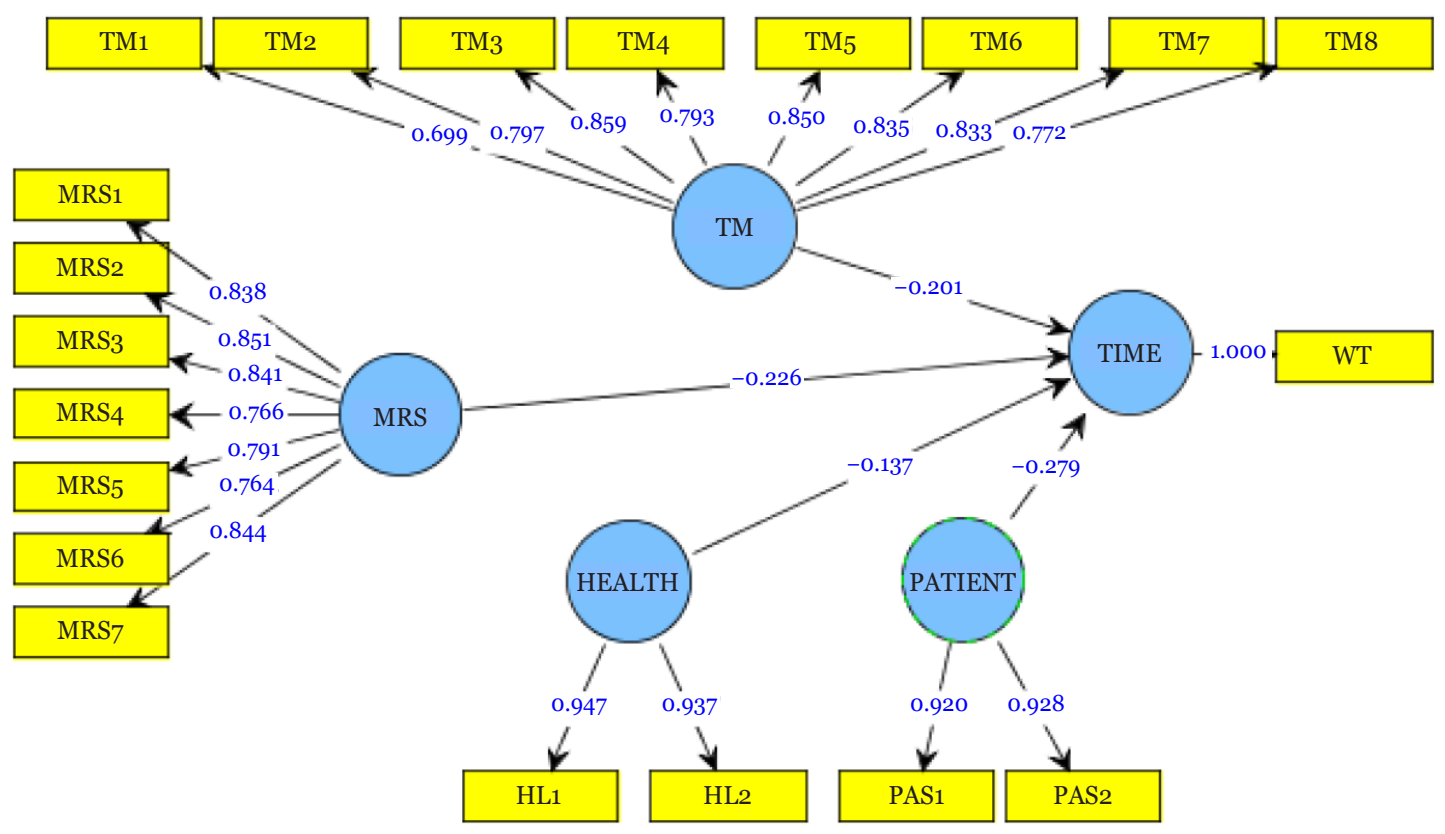

Figure Model of the Surgical Waiting Time

is the surgical waiting time (WT) variable. The complete relationship between the variables in this research is described in Figure.

The testing of structural models is carried out by testing the significance of each parameter. The test was carried out by comparing t statistics with t tables (at a $5 \%$ significance level) and then looking at the $\mathrm{R}^{2}$ value, a goodness-fit model test- 
Table 3 Parameter Coefficient

\begin{tabular}{lccc}
\hline Dimension & $\lambda$ & T-statistics & $\mathbf{R}^{2}$ \\
\hline TM $\rightarrow$ WT & -0.201 & 2.582 & 0.568 \\
MRS $\rightarrow$ WT & -0.226 & 4.600 & \\
HEALTH $\rightarrow$ WT & -0.137 & 1.562 & \\
PATIENT $\rightarrow$ WT & -0.279 & 3.928 & \\
\hline
\end{tabular}

the parameter coefficient test listed in Table 3.

The parameter coefficient of each exogenous latent variable was negative, meaning that there was an un-directional influence on WT. If TM increases by 1 unit, it will decrease WT by 0.201; if MRS increases by 1 unit, it will decrease WT by 0.226; if HEALTH increases by 1 unit, it will decrease WT by 0.137; if the PATIENT increases by 1 unit it will decrease WT by 0.279 . $\mathrm{R}$ square value of 0.568 showed that TM, MRS, HEALTH, and PATIENT were able to explain the WT construct variable as many as $56.8 \%$, and other constructs indicated the remaining as many as $43.2 \%$ besides TM, MRS, HEALTH, and PATIENT.

The effect of each variable partially and simultaneously is presented in Table 4. Based on Table 4, the obtained t value of TM, MRS, and PATIENT variables were 2.582, 46.00, and 3.928. Because the $t$ value for each of these variables was greater than the $\mathrm{t}$ table ( $\mathrm{t}$ table with a significance of $5 \%$ of 1.96), it concluded a significant influence of each variable was TM, MRS, and PATIENT on WT. The HEALTH variable had a statistical $t$ value as many as 1.562 because the value was lower than 1.96, meaning that there was no significant effect of HEALTH on WT.

Based on the simultaneous calculation test, it obtained that the F value (32.2130) was $>\mathrm{F}$ table (2.465). It indicated that TM, MRS, HEALTH, and PATIENT had a significant effect on waiting time (WT).

Based on Table 5, medical staff (TM) influence the surgical waiting time (WT) was $13.0 \%$, and management and hospital facilities (MRS) was $15.6 \%$. While the influence of health insurance (HEALTH) was 8.6\%; the influence of patient condition (PATIENT) was 19.6\%, and the total influence of the variables on waiting time was $56.8 \%$.

\section{Discussion}

The waiting time for cancer surgery in the West Java referral hospital has not met the Ministry of Health's minimum hospital standard, which is $\leq$ two days. At present, the number of surgical oncologists is only one; this is still lacking because the number of oncology patient visits to the clinic is quite high, with only three times per week of polyclinic service days. The number of inpatient rooms (beds), specifically surgery inpatient rooms with a total number of 52 beds, also causes the waiting time of surgery for cancer patients.

Based on the results of PLS analysis, the patient's condition factor is the most substantial value on waiting time because it has the most significant influence on cancer patient waiting time as much as $19.6 \%$. Observations made, and interviews with respondents indicated that the patient's condition is essential because the operation can be canceled if the patient's physical condition is getting worse. The medical preparation for each patient is different depending on the level of complexity of the operation and the risk of patient anesthesia. Patients with multimorbidity had a longer time to surgery than those without comorbidity among colorectal cancer patients in Spain. ${ }^{13}$

Several factors that cause changes in elective

Table 4 Partial and Simultaneous Effect of Variables to Waiting Time

\begin{tabular}{lccc}
\hline Partial Effect & $\lambda$ & T-Statistics & Conclusion \\
\hline TM $\rightarrow$ WT & -0.201 & 2.582 & Significant \\
MRS $\rightarrow$ WT & -0.226 & 4.600 & Significant \\
HEALTH $\rightarrow$ WT & -0.137 & 1.562 & Not significant \\
PATIENT $\rightarrow$ WT & -0.279 & 3.928 & Significant \\
Simultaneous Effect & \multicolumn{2}{c}{$\mathbf{R}^{\mathbf{2}}$} & \\
TM, MRS, HEALTH, and PATIENTS $\rightarrow$ WT & \multicolumn{2}{c}{0.568} & \\
\hline
\end{tabular}


surgery schedules are the patient's clinical condition and still need another examination. ${ }^{14}$ Coordination of imaging and clinical care reduces wait times in patients with abnormal screening mammograms and symptomatic breast presentations. ${ }^{15}$ In this research, respondents said that the patient's medical preparation did not significantly influence the waiting time for elective surgery. Medical preparations that must be passed by patients can usually be completed in one day. Patient characteristics, tumor biology, and stage do not influence time intervals from diagnosis to surgical treatment in breast cancers. ${ }^{16}$ However, there are still incidents when the surgery is canceled due to a decreased physical condition of the patient. It is an event that cannot be avoided or predicted. Prioritizing patients on the waiting list is usually carried out in two ways: assigning a priority score to each patient and categorizing patients into several priority classes with different service time targets. The development of homogenous waiting groups (HWG) is a promising tool for improving patients' prioritization of waiting to see a specialist or to receive a diagnostic test. ${ }^{17}$ Shorter wait times for most treatments for postmenopausal women diagnosed in the Breast Assessment Centre (BAC) further supports that women with an abnormal mammogram should be managed through organized assessment. ${ }^{18}$

The second factor influencing the waiting time of surgery for cancer patients in referral hospital is management and hospital facilities (MRS) as many as $15.6 \%$. The facility factor, especially the number of beds in the inpatient room, was still felt poor by both patients and hospital staff. Queues occur in the admission department. Currently, the hospital does not have a hospital management information system, so confirmation of the availability of inpatient rooms and the operating room is manually handled, thereby increasing waiting times. The number of beds available is 52 beds for surgical care. Inpatient rooms still have to adjust the needs of the class of patients' rooms. Currently, the most significant number is class 3 inpatient rooms, whereas overall national health insurance patients are treated in class 1 and class 2 rooms.

The third factor that influences waiting time is the number of medical staff as many as $13 \%$. Currently, the hospital only has one oncologist. Admittedly, this is not sufficient considering that the hospital is one of the Referral Hospital, so the low number of oncologist influence the length of waiting time. Hospital managers must quantify appropriate service capacity to meet the patient demand, balancing system utilization, and patient's wait time. ${ }^{19}$ Long waiting queues are symptomatic of inefficiency in-hospital services. Adding several doctors can effectively achieve optimal performance in the outpatient department at Anglo Gold Ashanti Hospital. ${ }^{20}$ The implementation of nurse navigation for breast cancer patients is effective in reducing wait times for surgical treatment in Canada. ${ }^{21}$

Another factor that influences surgery wait time is health insurance. Patients with statutory insurance are more likely to report long waiting times for examinations, discharge, and to speak with the physician than private insurance holders. ${ }^{22}$ State-level Medicaid policies (joint federal-state program covering health care services to low-income population) and patient characteristics can affect receipt of timely surgery among Medicaid beneficiaries with breast cancer. ${ }^{23}$ In Indonesia, the form of compulsory or statutory health insurance is the JKN-BPJS participant.

The administration of national insurance (BPJS) participants considered having an effect on $8.6 \%$ on the waiting time of cancer patients' surgery in this hospital. In general, the referral administration requirements were considered quite good and easy by most respondents. There are administrative differences that must be completed by BPJS patients, namely the Surgery Proof Letter file. The stipulation of this policy is carried out to minimize the cancellation of essential operations before enacting the policy. The waiting time for the emergency operation is also associated with informed consent from the family or the insurance, human resource, and the equipment of operation. ${ }^{24}$

The number of nurses and specialist surgeons positively influence waiting times. ${ }^{25}$ Based on the observation, the surgical oncologist is only one person and felt still lacking, but this was considered less important by respondents in influencing waiting times because five general surgeons at the hospital could still do cancer surgery.

The availability of sufficient human resources and followed by high-quality professionals following their functions and duties is one indicator of an effective and efficient hospital success. The lack of HR in the Central Surgical 
Installation can affect the service process to patients, which results in suboptimal service to patients. The problem of the number of human resources that are not following needs can affect waiting times. Lack of human resources has resulted in the delay of surgery and disruption of processes in the operating room. ${ }^{26}$ According to observations and interviews conducted by the research team, the lack of human resources influences waiting time, but it is not significant.

\section{Conclusion}

Based on the formulation of the problem, the results of the study, and the discussion presented earlier, the conclusions can be drawn as follows: the waiting time for cancer surgery on national health insurance (BPJS) patients at west java referral hospital are 32 days, the factors that influence the waiting time for cancer surgery was the condition of patients (19.6\%), hospital facilities and management (15.6\%), medical personnel (13\%) and health insurance (BPJS). The optimal queuing model to reduce operating WT in West Java Referral Hospital is by adding inpatient beds, surgical oncologists, and creating an online system for registration and confirmation of inpatient and operating room readiness.

\section{Conflict of Interest}

No conflict of interest.

\section{Acknowledgments}

The Indonesian National Health Insurance (BPJS Kesehatan) funded this research.

\section{References}

1. Susanti Y, Azis Y, Kusnadi D. Pengaruh appointment registration system terhadap waktu tunggu dan kepuasan pasien. GMHC. 2015;3(1):40-7.

2. Pusat Data dan Informasi Kementerian Kesehatan Republik Indonesia. Situasi penyakit kanker [Internet]. Jakarta: Kementerian Kesehatan Republik Indonesia; 2015 [cited 2019 November 15]. Available from: https://pusdatin.kemkes.go.id/ resources/download/pusdatin/infodatin/ infodatin-kanker.pdf.

3. Ferlay J, Ervik M, Lam F, Colombet M,
Mery L, Piñeros M, et al. Global Cancer Observatory: cancer today: population fact sheets [Internet]. Lyon, France: International Agency for Research on Cancer; 2018 [cited 2019 November 16]. Available from: https://gco.iarc.fr/today/data/factsheets/ populations/900-world-fact-sheets.pdf.

4. Bray F, Ferlay J, Soerjomataram I, Siegel RL, Torre LA, Jemal A. Global cancer statistics 2018: GLOBOCAN estimates of incidence and mortality worldwide for 36 cancers in 185 countries. CA Cancer J Clin. 2018;68(6):394-424.

5. Badan Penelitian dan Pengembangan Kesehatan, Kementerian Kesehatan Republik Indonesia. Riset kesehatan dasar (Riskesdas) 2013. Jakarta: Kementerian Kesehatan Republik Indonesia; 2013.

6. Keputusan Menteri Kesehatan Republik Indonesia Nomor 129/Menkes/SK/II/2008 tentang Standar Pelayanan Minimal Rumah Sakit.

7. Fitri AN. Analisis waktu tunggu operasi elektif pasien rawat inap di Instalasi Bedah Sentral Rumah Sakit Kanker Dharmais tahun 2014 [undergraduate thesis]. Depok: Universitas Indonesia; 2014 [cited 2019 November 16]. Available from: http://lib. ui.ac.id/naskahringkas/2016-05/S55565Anasatia\%20Nuansa\%20Fitri.

8. Humas RSUP Dr. Hasan Sadikin. Kanker bukan di luar kemampuan kita [Internet]. Bandung: RSUP Dr. Hasan Sadikin; 2015 [cited 2019 November 17]. Available from: http://web.rshs.or.id/kanker-bukan-diluarkemampuan-kita.

9. Nilssen Y, Brustugan OT, Eriksen MT, Gulbrandsen J, Haug ES, Naume B, et al. Decreasing waiting time for treatment before and during implementation of cancer patient pathways in Norway. Cancer Epidemiol. 2019;61:59-69.

10. Wright JG, Menaker RJ, Canadian Paediatric Surgical Wait Times Study Group. Waiting for children's surgery in Canada: the Canadian Paediatric Surgical Wait Times project. CMAJ. 2011;183(9):E559-64.

11. Ferdinand A. Structural equation modeling dalam penelitian manajemen: aplikasi model-model rumit dalam penelitian untuk skripsi, tesis dan disertasi doktor. $5^{\text {th }}$ Edition. Semarang: Badan Penerbit Universitas Diponegoro: 2014. 
12. Sholiha EUN, Salamah M. Structural equation modeling-partial least square untuk pemodelan derajat kesehatan kabupaten/ kota di Jawa Timur (studi kasus data indeks pembangunan kesehatan masyarakat Jawa Timur 2013). J Sains Seni ITS. 2015;4(2):16974.

13. Luque-Fernandez MA, Redondo-Sanchez D, Lee SF, Rodríguez-Barranco M, CarmonaGarcía MC, Marcos-Gragera $\mathrm{R}$, et al. Multimorbidity by patient and tumor factors and time-to-surgery among colorectal cancer patients in Spains: a population-based study. Clin Epidemiol. 2020;12:31-40.

14. Sangkot HS. Mortalitas dan morbiditas pada pasien elektif dalam daftar tunggu operasi bedah pintas koroner di Unit Pelayanan Fungsional (UPF) Bedah Jantung dan Intermediate Bedah Dewasa RS Jantung dan Pembuluh Darah Harapan Kita tahun 2010 [thesis]. Depok: Universitas Indonesia; 2010 [cited 2019 November 17]. Available from: http://lib. ui.ac.id/file?file = digital $/ 20313277-\mathrm{T} \% 20$ 31717-Mortalitas\%2odan-full\%2oetxt.pdf.

15. McKevitt E, Dingee C, Warburton R, Pao JS, Brown CJ, Wilson $\mathrm{C}$, et al. Patient navigation reduces time to care for patients with breast symptoms and abnormal screening mammograms. Am J Surg. 2018;215(5):80511.

16. Mariella M, Kimbrough CW, McMaster KM, Ajkay N. Longer time intervals from diagnosis to surgical treatment in breast cancer: associated factors and survival impact. Am Surg. 2018;84(1):63-70.

17. Mariotti G, Siciliani L, Rebba V, Fellini R, Gentilini M, Benea G, et al. Waiting time prioritisation for specialist services in Italy: the homogeneous waiting time groups approach. Health Policy. 2014;117(1):54-63.

18. Blackmore KM, Weerasinghe A, Holloway CMB, Majpruz V, Mirea L, O'Malley FP, et al. Comparison of wait times across the breast cancer treatment pathway among screened women undergoing organized breast assessment versus usual care. Can J Public Health. 2019;110(5):595-605.
19. Palvannan RK, Teow KL. Queueing for healthcare. J Med Sys. 2012;36(2):541-47.

20. Afrane S, Appah A. Queuing theory and the management of waiting-time in hospital: the case of Anglo Gold Ashanti Hospital in Ghana. Int J Acad Res Bus Soc Sci. 2014;4(2):34-44.

21. Baliski C, McGahan CE, Liberto CM, Broughton S, Ellard S, Taylor M, et al. Influence of nurse navigation on wait times for breast cancer care in a Canadian regional cancer center. Am J Surg. 2014;207(5):68692; discussion 691-2.

22. Lee S, Gross SE, Pfaff H, Dresen A. Differences in perceived waiting time by health insurance type in the inpatient sector: an analysis of patients with breast cancer in Germany. Inquiry. 2019;56:46958019875897.

23. Halpern MT, Schrag D. Effect of state-level medicaid policies and patient characteristics on time to breast cancer surgery among medicaid beneficiaries. Breast Cancer Res Treat. 2016;158(3):573-81.

24. Mashuri A. Analisis faktor-faktor yang berhubungan dengan waktu tunggu persiapan operasi cito di Instalasi Gawat Darurat Rumah Sakit Karya Medika I Kabupaten Bekasi tahun 2011 [thesis]. Depok: Universitas Indonesia; 2012 [cited 2019 November 18]. Available from: http:// lib.ui.ac.id/file?file = digital/20298035T30149-Aman\%2oMashuri.pdf.

25. Mervin MC, Jackson S. How can we improve waiting time for elective surgery in Australian public hospital. Discussion Paper No. 387 [Internet]. St Lucia, Brisbane: The University of Queensland; 2009 [cited 2019 November 20]. Available from: https:// espace.library.uq.edu.au/view/UQ:176138/ DP387March2009.pdf.

26. Askar M. Analisis penyebab keterlambatan dimulainya operasi elektif di Instalasi Kamar Bedah Rumah Sakit Otorita Batam [thesis]. Depok: Universitas Indonesia; 2011 [cited 2019November 21].Availablefrom:http://lib. ui.ac.id/file?file=digital/20308042-T\%20 31668-Analisis\%2openyebab-full\%2otext. pdf. 